\title{
Rapidly progressive sporadic Creutzfeldt-Jakob disease: isolated Heidenhain variant or a combination with PRES?
}

\author{
Doença de Creutzfeldt-Jakob esporádica rapidamente progressiva: variante Heidenhain \\ isolada ou PRES combinada?
}

Pedro Henrique Almeida FRAIMAN¹, Carolina Militão TEIXEIRA', Juliano César Dantas DE OLIVEIRA²,
Thadeu Alexandre Paulino DE SOUSA², Manuel MOREIRA-NETO³, Clecio de Oliveira GODEIRO-JUNIOR

A 70-year-old man presented with rapidly progressive cognitive impairment with ataxia and myoclonus. Visual agnosia was noticed after blood pressure oscillations, during immunoglobulin therapy for suspected autoimmune encephalitis. Brain magnetic resonance imaging scans before and after visual agnosia are presented in Figure 1. Electroencephalogram disclosed periodic sharp wave complex, and cerebrospinal fluid was positive for 14-3-3 protein. The final diagnosis was probable Creutzfeldt-Jakob disease (CJD) associated with posterior reversible encephalopathy syndrome (PRES). Blood pressure and immunoglobulin therapy may explain PRES ${ }^{1}$. It seems that some types of CJD prion proteins could induce the activation of microglia and dysfunction of vasoconstrictors upregulation, leading to vasospasm, ischemia and PRES ${ }^{1,2}$

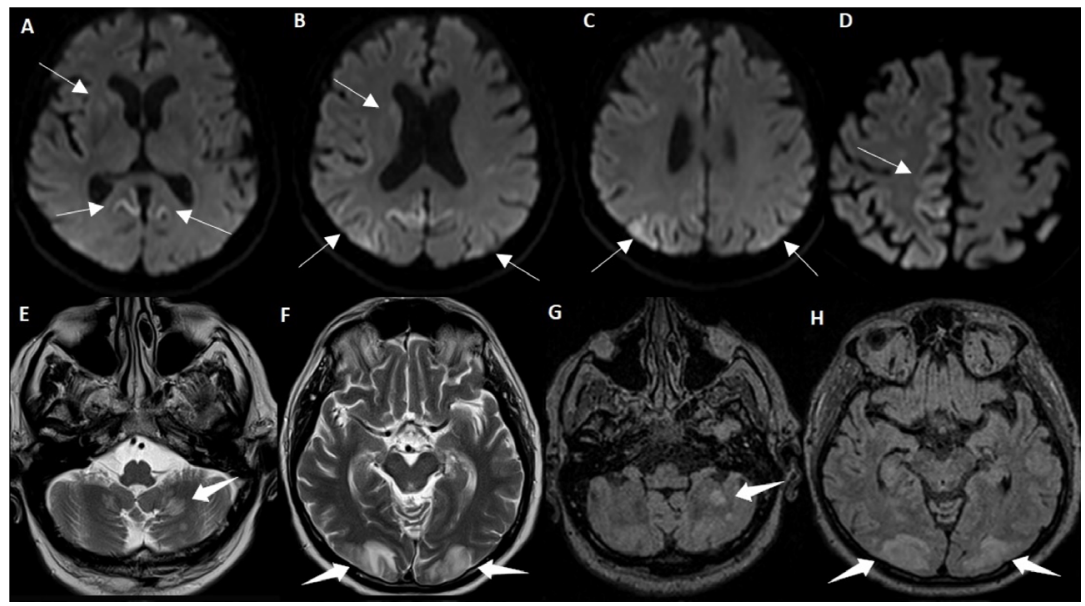

Figure 1. Magnetic resonance imaging features of sporadic Creutzfeld-Jakob disease and posterior reversible encephalopathy syndrome. (A, B, C and D) Initial diffusion-weighted images revealing bilateral hyperintensities in parietal areas, mostly on the right, and hyperintensities in cingulate gyrus. The same findings apply albeit to a lesser extent in the right basal ganglia (caudate and putamen, white arrows). (E, F, G and H) T2WI and T2-fluid-attenuated inversion-recovery reveals new cortico-subcortical hyperintensities in parietal and occipital areas and cerebellum, compatible with vasogenic edema, highly suggestive of PRES (thick white arrows). Previously described alterations remain the same. T1W1 does not reveal contrast enhancement.

\footnotetext{
${ }^{1}$ Universidade Federal do Rio Grande do Norte, Hospital Universitário Onofre Lopes, Divisão de Neurologia, Natal RN, Brazil.

${ }^{2}$ Casa de Saúde São Lucas, Divisão de Radiologia, Natal RN, Brazil.

${ }^{3}$ Universidade Federal do Rio Grande do Norte, Hospital Universitário Onofre Lopes, Divisão de Radiologia, Natal RN, Brazil.

Pedro Henrique Almeida FRAIMAN (D) https://orcid.org/0000-0002-5250-8602; Carolina Militão TEIXEIRA (DD https://orcid.org/0000-0003-0990-5044; Juliano César Dantas DE OLIVEIRA (iD https://orcid.org/0000-0002-3079-6885; Thadeu Alexandre Paulino DE SOUSA (iD https://orcid.org/0000-0001-9568-3411; Manuel MOREIRA-NETO (iD https://orcid.org/0000-0002-3478-5323; Clecio de Oliveira GODEIRO-JUNIOR (iD) https://orcid.org/0000-0002-4312-1633 Correspondence: Clecio Godeiro-Junior; E-mail: cleciojunior@yahoo.com.br

Conflict of interest: There is no conflict of interest to declare.

Authors' contributions: PF: analysis and interpretation, writing and drafting the manuscript; CMT: data acquisition, analysis and interpretation, writing the manuscript; JCDO: data acquisition, analysis and interpretation; TAPS: data acquisition, analysis and interpretation; MMN: critical revision of the manuscript for intellectual content; CGJ: critical revision of the manuscript for intellectual content.

Received on September 04, 2020; Accepted on September 19, 2020.
} 


\section{References}

1. Dirzius E, Balnyte R, Steibliene V, Gleizniene R, Gudinaviciene I, Radziunas A, et al. Sporadic Creutzfeldt-Jakob disease with unusual initial presentation as posterior reversible encephalopathy syndrome: a case report. BMC Neurol. 2016 Nov;16(1):234. https:// doi.org/10.1186/s12883-016-0751-8
2. Freitas CS, Pinheiro MGM, Fonte EJD, Hazin AN, Smid J, Barbosa BJAP. Posterior cortical ribboning in the Heidenhain variant of Creutzfeldt-Jakob Disease. Arq Neuro-Psiquiatr. 2020 Apr;78(4):241. https://doi.org/10.1590/0004-282×20190176 